\title{
Investigation on the Natural Enemies of Jute Yellow Mite and Their Performances and Seasonal Incidence
}

\author{
Md. Nazrul Islam ${ }^{1}$, Khandakar Shariful Islam², Mahbuba Jahan² \& Md. Sohanur Rahman ${ }^{3}$ \\ ${ }^{1}$ Principal scientific officer, Pest management Division, Bangladesh Jute Research Institute, Manik Mia Avenue, \\ Dhakia-1207, Bangladesh \\ ${ }^{2}$ Professor, Department of Entomology, Bangladesh Agricultural University, Mymensingh. \\ ${ }^{3}$ Scientific Officer, Pest management Division, Bangladesh Jute Research Institute, Manik Mia Avenue, Dhakia- \\ 1207, Bangladesh
}

Correspondence: Md. Sohanur Rahman, Scientific Officer, Pest management Division, Bangladesh Jute Research Institute, Manik Mia Avenue, Dhakia-1207, Bangladesh. E-mail: sohanbau2010@gmail.com

Received: March 5, 2020 Accepted: March 22, 2020 Online Published: March 29, 2020

\begin{abstract}
The jute yellow mite Polyphagotarsonemus latus constitutes one of the major pests of jute crop in Bangladesh. The objective of this work was to investigation on the natural enemies of jute yellow mite. The investigation on the natural enemies of jute yellow mite were studied in the laboratory of Bangladesh Jute Research Institute during March 2011 to September 2013. As many as six predators of jute yellow mite viz, Predatory mite, Thrips, Minute pirate bug, Lady bird beetle, Mirid bug and Spider were collected and identified. The predation rate of the predatory mite Amblyseius sp. showed an average of 8.8 jute yellow mite per hour in laboratory condition. Predatory mite reached the peak on the $20^{\text {th }}$ June. The highest population was 25 predatory mite/ 25 leaves. The population of predatory mite declined sharply in the ${ }_{1}^{\text {st }}$ week of July. The nymph and adult of Scolothrips consumed an average of 15.4 and 20.10 yellow mite per hour. Scolothrips sp reached its peak population on $30^{\text {th }}$ June and declined occurred in the $1^{\text {st }}$ week of July. Both nymph and adult stage of Orius sp. predate 24.5 and 21 jute yellow mite respectively. The highest number of Minute pirate bug 20 was recorded at $30^{\text {th }}$ June. Both the grubs and adults of lady bird beetle predate on all the stage of yellow mite. Grub was found as voracious feeder showing a predation efficiency of 35 per hour. The highest and lowest number of Ladybird beetle was recorded on $25^{\text {th }}$ June and $5^{\text {th }}$ May respectively. The highest 15 Mirid bug was recorded at $30^{\text {th }}$ June. An unidentified species of spider was found to consume yellow mite.
\end{abstract}

Keywords: natural enemies, investigation, performance, jute yellow mite

\section{Introduction}

The genus Corchorus belonging to the family Tiliaceae, is commonly known as jute. There are 2 species of jute namely, Corchorus capsularis L. and C. olitorius L. Jute is most important cash crop and one of the foreign currency earning sources of Bangladesh as the culture of higher expression of economy. Jute is attacked by various insect and mite pests. More than 40 species of insects and mites are considered to be the pests of jute in Bangladesh (Kabir, 1975). Among the non-insect pests yellow mite, Polyphagotarsonemus latus (Banks) (Acari: Tarsonemidae) is one of the most common and destructive pests of both the cultivated species of jute (C.capsularis L. and C. olitorius L.). It was first described by Banks in 1904 as Tarsonemus latus from the terminal buds of mango in a greenhouse in Washington, D.C., USA (Denmark, 1980).

The yellow mite is commonly known as yellow tea mite which is also called as the broad mite. In India and Sri Lanka, it is called yellow tea mite. However, some parts of the South America, it is called tropical mite or the broad rust mite (Anonymous, 2005a). Yellow mite is extremely polyphagous and attack more than 60 plant families worldwide (Karuppuchamy and Mohanasundaram, 1987; Moutia, 1958; Nemesthoty et al., 1982; Iacob, 1978).

Yellow mite infestation in jute normally begins on the young apical leaves and causes damage by sucking of the plant sap resulting in wrinkle and curly appearance of tender leaves. Gradually, the colour of the leaves change to coppery or purplish, finally dry up and fall down (Siddique and Kabir, 1978). The vertical growth of the internodes is suppressed thereby side branches are enhanced (Kabir, 1975). The infested plant remains stunted and fibre yield 
is reduced. It has been reported that about $38 \%$ of fibre yield is reduced due to attack of yellow mite under field condition (Anonymous, 1990). Yellow mite also attacks flower buds and young seed pods. The infested flower buds cannot bloom properly. The floral parts become crinkled and the colour changes yellow to a blackish. The seed pod fails to develop which results in reduced seed production (Siddique and Kabir, 1978). The damage caused by the yellow mite is often termed as "Telenga" or "Telchita" disease in Bangladesh (Kabir,1975). Different control measures e.g. physical, mechanical, cultural and chemical control are practiced against yellow mite, but none of them provides effective control. So far, a good number of acaricides have been evaluated by BJRI and considered as the most effective methods for the control of yellow mite. However, chemical acaricides have some limitations. The non-judicious use of synthetic chemicals for the control of mite pests creates several problems in agro-ecosystem, such as direct toxicity to beneficial insects, fishes and human (Goodland et al., 1985, Pimentel 1981, Munakata 1977) gain resistance to chemicals (Schmutterer et al., 1983, Waiss and Chen 1981, Georghiou and Taylor 1977, Fukuda 1966) out breaks of secondary pests (Hagen and Franz 1973), health hazarads (Bhaduri et al. 1989), environmental pollution (Fishwick 1988, Kavadia et al.1986), susceptibility of crop plants to insect pests (Pimentel ,1977) and increases environmental and social cost (Pimentel ,1981). In general, chemical control of pests by different pesticides is a very health hazardous, costly and they kill not only the pests but also their parasite, predators and create imbalance in environment. The indiscriminate and excessive use of pesticides, on the other hand have created new problems like resurgence of minor pests and insects developing resistance to insecticides. Therefore, research is being done to find out suitable eco-friendly pest control measures against the mite pest.

Therefore, to minimize the use of synthetic chemicals in mite control programmes, alternative or biodegradable substitutes are now strongly needed in many developed countries. Biological control of pests is one of the most important components of integrated pests management. Biological control with use of predators, parasites or pathogens is a viable alternative to chemical control measures. Natural enemies can either be native or introduced. The use of natural enemies prevents environmental risks associated with chemical pesticides, while sustainably protecting the crop given that the biological control agent does not cause any harmful non-target effects. Biological control is considered as a natural phenomenon of regulation of insect pests numbers by biotic mortality factors such as parasites, predators, disease and extremes of weather that keeps pests in a state of balance.

It is quite apparent that naturally occurred biotic agents especially the parasitoid, predators, pathogens and their utilization has utmost effect in pests control and this technique has received more attention as it is relatively safe, permanent, self-renewing and less expensive. Entomologists have given attention to identify and use of bio-control agent. Till now some predators, parasites have been detected as natural enemies of jute mite.

The present investigations were undertaken with the objective to identify the natural enemies of jute yellow mite with their potentiality as bio-control agent.

\section{Materials and Methods}

\subsection{Survey for Existing Natural Enemies of Yellow Mite}

Data were collected through random sampling from ten selected plots where no chemicals were applied. Natural enemies were observed though observation of leaves only and whole plant searching

\subsection{Leaf Searching}

Infested plants were selected randomly from which mite infested leaves were collected and observed under stereo microscope for the presence of any predator(s).

\subsection{Whole Plant Observation}

From each plot 25 yellow mite infested plants were selected randomly and observed with care separately through naked eye to record the presence of larger sized predators.

\subsection{Preservation of the Predators}

The collected predators were preserved for identification. The natural enemy specimens were preserved using the following preservation methods:

i) Dry method: Paper tips mounting

ii) Semi- permanent method- By using Canada balsam whole mount slide

iii) In liquid- At immature stage in alcoholic solution 


\subsection{Identification of the Predators}

The predators were identified with the taxonomic literature, expert scientists and university teachers. Some of the predators are the new record of jute field in Bangladesh. Some predators could not be identified due to the lack of specific key (literature).

\subsection{Seasonal Incidence}

Infested leaves and twigs were collected from the field and observed under the stereo-microscope at 5 days intervals during the infestation period from April to September. Field temperature and relative humidity was also recorded during the study period. Population level of specific predator in different months was documented.

\subsection{Predation Rate}

Predation performance of different predators of yellow mite was observed through monitoring hourly consumption of the mite prey by specific predator. The prey consumption was studied using stereo- microscope.

\section{Results}

\subsection{Predatory mite- (Amblyseius sp.), Family: Phytoseiidae}

The predatory mite, Amblyseius $s p$. is an important predator as it was found throughout the jute growing season. A good number of predatory mite species of the family Phytoseiidae attack yellow mite.

\subsubsection{Systematic Position of the Predatory Mite}

Phylum: Arthropoda

Class: Arachnida

Order: Acarina

\section{Family: Phytoseiidae}

Genus: Amblysieus

\subsubsection{Description}

The predatory mite, Amblysieus sp. is straw-coloured to almost white, depending on age and recent food sources. It is more flattened in shape than the relatively dome-shaped spider mites. When viewed from above, Amblyseius is oval to somewhat pear-shaped. Usually teardrop-shaped, long legged.

\subsubsection{Searching Behaviour}

The predatory mite, Amblysieus sp. was found to move quickly through and around in search of prey. Unlike spider mites, it moved backwards as well as forwards. At the noon the activity of adult predatory mite was found mainly restricted to shady area but they were highly active in all the areas of leaf and shoot during the morning and evening time of the day.

\subsubsection{Prey Consumption}

Amblyseius feeds on a variety of mite species, but exhibits a little cannibalistic behaviour. It is capable of consuming all the life stages of the prey. Both the immature and mature stages can attack the yellow mite of jute. In the present study the predation performance of only adult stage of the Amblyseius sp. was investigated. The predation performance of the mite was studied in the average room temperature of $26.75 \pm 0.09$ and relative humidity of $72.08 \pm 0.33$. The predation rate of Amblyseius sp. was recorded on an average $8.8 \pm 0.84$ jute yellow mite (egg, nymph and adult) per hour in laboratory condition. 


\subsubsection{Seasonal Incidence of the Predatory Mite Amblyseius sp.}

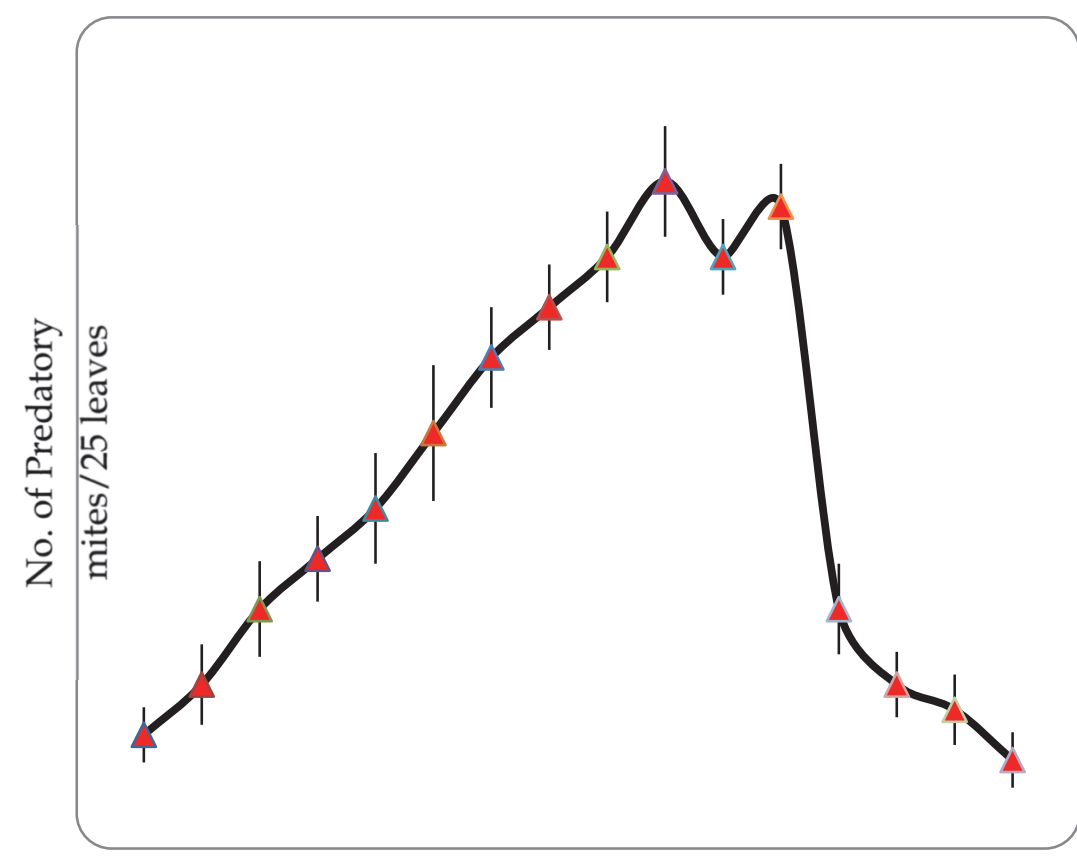

Date of observation

Figure 1. Seasonal incidence of Amblyseius sp. in experimental field in Central station, BJRI during 2012

The results of incidence of the predatory mite, Amblyseius sp. are presented in the Figure 1. This particular predatory mite was present in the jute field during the period from May to July. It was first noticed on the $5^{\text {th }}$ of May when only 3 predatory mite were found/25 leaves of jute plant. Then the population of predatory mite increased steadily with the progration of the month. It reached the peak on the $20^{\text {th }}$ June and maintained similar level up to the end of the June. The highest population was 25 predatory mite/25 leaves. The population of the predatory mite then declined sharply in the $1^{\text {st }}$ week of July. There after it was found to reduced population level slowly until the end of July.

\subsection{Thrips, Scolothrips sp.}

Thrips, Scolothrips sp. is considered as a good predator of jute yellow mite. It has not been reported earlier as a predator of jute yellow mite in Bangladesh. It was found only in the areas of high yellow mite infestation. It disappeared as soon as the population of the yellow mite decreased.

\subsubsection{Systematic Position}

\section{Phylum: Arthropoda}

Class: Insecta

Order: Thysanoptera

Family: Thripidae

\section{Genus: Scolothrips}

\subsubsection{Description}

The thrips are yellow and red in colour but at the nymphal stage they are transparent or whitish in colour. They are very small in size and the length is about only $1 / 2 \mathrm{~mm}$. They have short live span and complete their whole life within a week.

\subsubsection{Searching Behavior}

Both the nymph and adult are very active but adult were more active. When the leaf was touched then the adults were found to move by inverse jumping. At the period of high sun the thrips were found to be restricted to shady area. They were highly active in all the areas in search of the prey during the morning and evening time of the day. 


\subsubsection{Prey Consumption of Thrips}

Table 1. Predation rate of the predator, Scolothrips sp. per hour under laboratory condition of BJRI, Dhaka

\begin{tabular}{ll}
\hline Stages of predator, Scolothrips sp. & Predation rate/hr (Mean \pm SE) \\
\hline Nymph & $15.4 \pm 0.33$ \\
Adult & $20.10 \pm 0.38$ \\
Room temperature $\left({ }^{\circ} \mathrm{C}\right)$ & $26.46 \pm 0.10$ \\
Relative Humidity $(\%)$ & $72.43 \pm 0.41$
\end{tabular}

Both nymph and adult predate on yellow mite irrespective of egg, nymph or adult preferably egg. The predation performance of the adult was higher than that of the nymph of the thrips (Table1). The nymph and adult of Scolothrips consumed an average of 15.4 and 20.10 yellow mite per hour at the temperature of $26.46 \pm 0.10^{\circ} \mathrm{C}$ and relative humidity $72.43 \pm 0.41 \%$.

3.2.5 Seasonal Incidence of Predatory Thrips

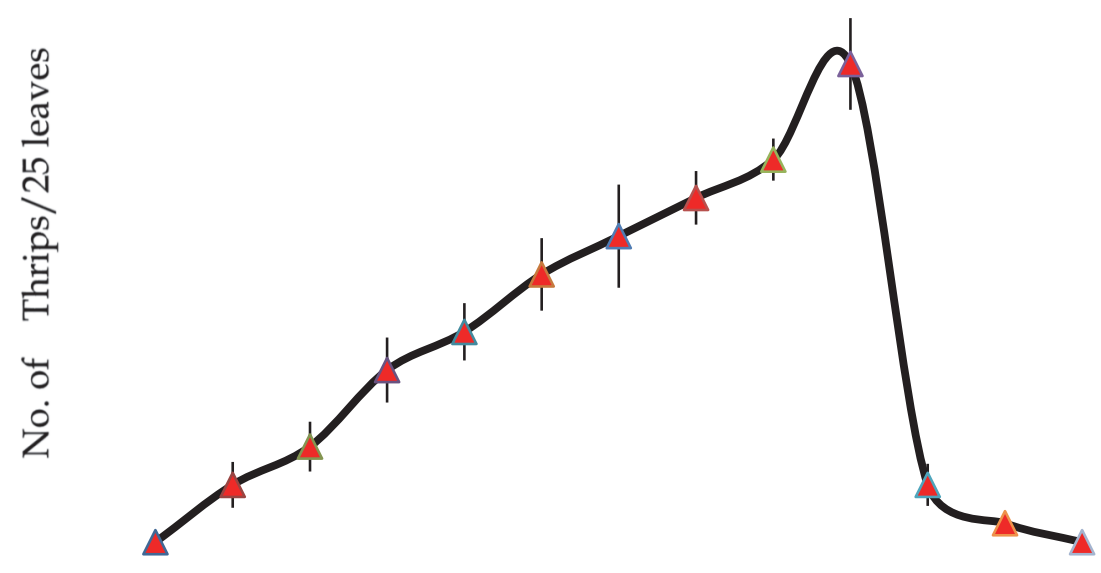

Date of Observation

Figure 2. Seasonal incidence of Scolothrips sp. in experimental field, Central station, BJRI, Dhaka during 2012

The predatory thrips Scolothrips sp. was found in the jute field during the period from May to July (Figure2). It was first evident after mid May then it started to increase its number steadily up to the end of June. It reached its peak population of 25 on $30^{\text {th }}$ June. There after a sharp decline occurred in the $1^{\text {st }}$ week of July. which then decline further up to the middle of July. No thrips was found available in the later part of July and onward.

\subsection{Minute Pirate Bug (Orius Insidiosus)}

3.3.1 Systematic Position

Phylum: Arthropoda

Class: Insecta

\section{Order: Hemiptera}

Family: Anthocoridae

Genus: Orius

Species: Orius insidiosus 


\subsubsection{Description}

Among the identified predators Orius insidiosus was found the most numerous in the studied area. It was observed that adult and nymphs of Orius insidiosus stay at the lower surface of the tender leaf of the topmost portion of the jute plants. It was also found at tender stipule. It could be considered as a good predator of yellow mite of jute.

\subsubsection{Searching Behaviour}

In pursuit of the prey Orius move from to and fro and when it get any prey it pierce the body at the dorsal side of the prey jute yellow mite or dorso- ventral side of it and suck the body sap except the exuviae. A predator individual was found to predate 8-10 yellow mites one after another at a time and then take rest for several times. It was also observed that their feeding tendency varied with the period of the day. It the morning time their feeding tendency is low and with day passing of time it increases to very high at the noon which decreases again as the progresses towards evening.

3.3.4 Predation rate of minute pirate bug

Table2. Predation rate of the predator, O. insidiosus in laboratory condition of BJRI, Dhaka, during 2012

\begin{tabular}{ll}
\hline \multicolumn{1}{c}{ Stage of predator } & Predation rate/hr (Mean $\pm \mathrm{SE})$ \\
\hline Nymph & $24.5 \pm 1.47$ \\
Adult & $21 \pm 1.45$ \\
Room tempetrature $\left({ }^{\circ} \mathrm{C}\right)$ & $26.65 \pm 0.12$ \\
Relative Humidity $(\%)$ & $73.3 \pm 0.72$ \\
\hline
\end{tabular}

The predation rate of Minute pirate bug at noon is shown in the Table2. Both nymph and adult stage of Orius sp. predate yellow mite. This predator predate on all the stages (egg nymph and adult) of the jute yellow mite. A nymph of Orius sp. predates $24.5 \pm 1.47$ egg, nymph and adult of yellow mite per hour. Whereas an adult minute pirate bug predates including all stage of yellow mite $21 \pm 1.45$ per hour.

\subsubsection{Seasonal Incidence of Minute Pirate Bug}

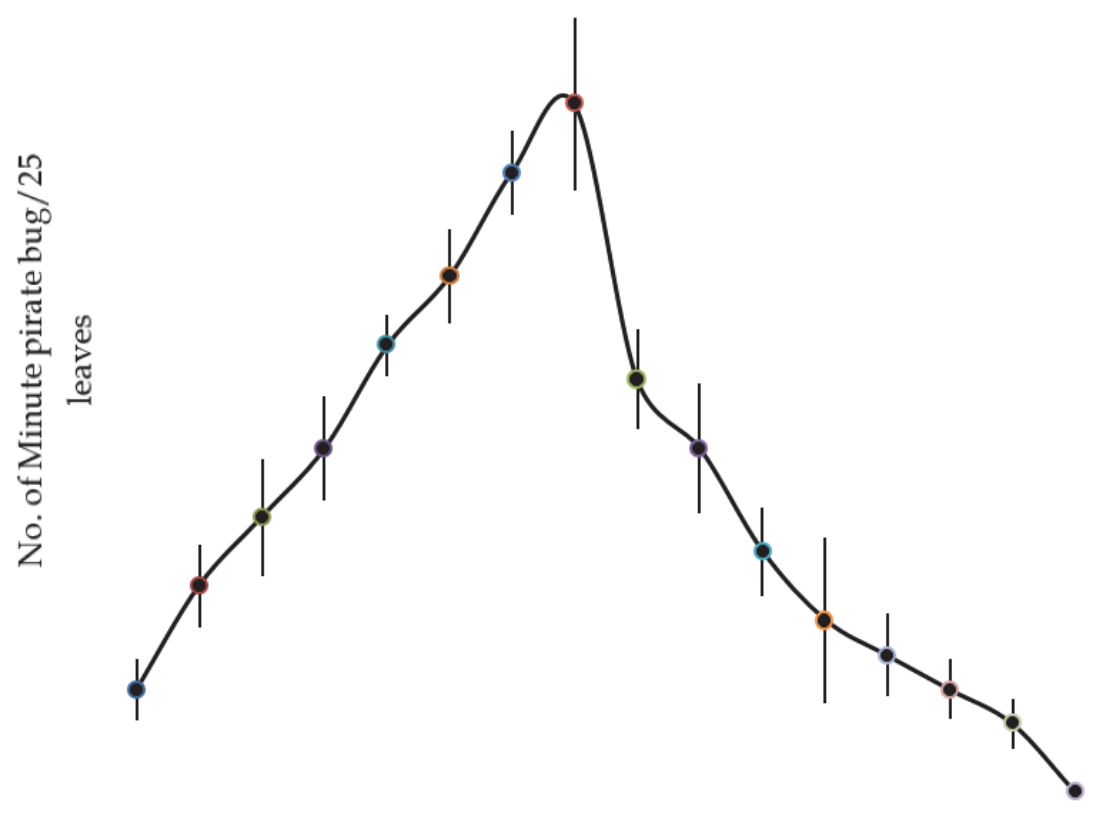

Date of Observation

Figure 3. Seasonal incidence of Orius insidiosus in experimental field in central station, BJRI during 2012 
The incidence of Miute pirate bug was observed at the $25^{\text {th }}$ May to $5^{\text {th }}$ August (Figure3). Minute Pirate bug showed and increasing trend of its population on the last week of May to the end of June. After reaching to the peak the population of the Minute pirate bug decreased continously and reached to zero on the $2^{\text {nd }}$ week of August.

The highest number of Minute pirate bug 20 was recorded at $30^{\text {th }}$ June. On the other hand, the lowest number of Minute pirate bug 2 was recorded at $5^{\text {th }}$ August.

\subsection{Lady Bird Beetle}

Lady bird is usually the most important and frequent predator of red mites. But it is also found to predate on yellow mite to a considerable extent.

\subsubsection{Systematic Position}

Phylum: Arthropoda

Class: Insecta

\section{Order: Coleoptera}

Family: Coccinellidae

Genus: Coccinella

Species: Coccinella transversalis

\subsubsection{Description of the Lady Bird Beetle}

Adults are oval, convex, black and orange in colour. Eggs are very small in size, pale white and oval. Larva is gray to blackish and yellow patches.

\subsubsection{Searching behaviour}

They are mainly located under surface of leaves where there are mites of different stages in abundant quantity. They move all around from tender leaves to older leaves of the jute plants. Activity was high at the morning and evening time.

\subsubsection{Predation Rate of Lady Bird Beetle}

Table 3. Predation rate of the predator, Ladybird beetle per hour in the laboratory condition, BJRI during 2012

\begin{tabular}{ll}
\hline Stage of predator & Predation rate/hr (Mean \pm SE) \\
\hline Grub & $35.70 \pm 1.80$ \\
Adult & $3.8 \pm 0.73$ \\
Room temperature & $26.98 \pm 0.23$ \\
\% Relative Humidity & $71.23 \pm 0.31$ \\
\hline
\end{tabular}

Both the grubs and adults predate on all the stage of yellow mite. Grub was found as voracious feeder. Predation efficiency was higher in the grub stage than the adult Table 3. Grub predates on an average of $35 \pm 1.80$ individuals per hours where as adult predate only $3.8 \pm 0.73$ in number per hour. Feeding tendency of adult on the yellow mite reduced markedly to a minimum level. 


\subsubsection{Seasonal Incidence of Ladybird Beetle}

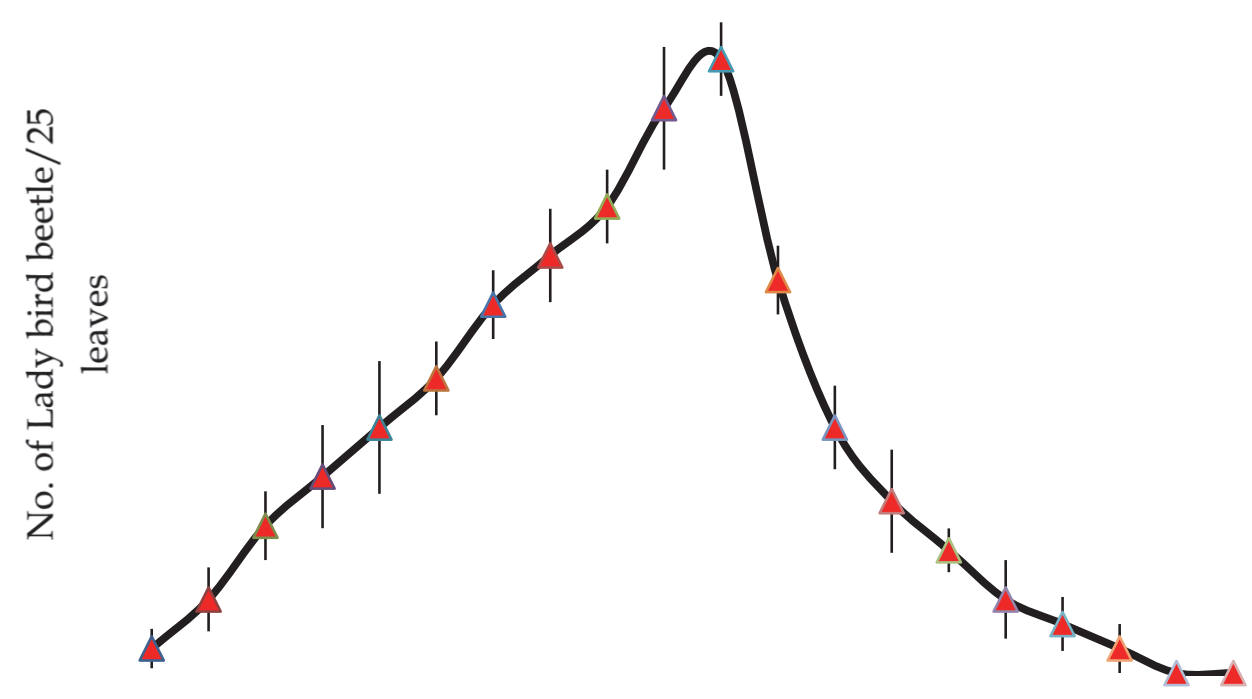

Date of Observation

Figure 4. Incidence of Lady bird beetle in experimental field in Central station, BJRI during 2012

The incidence of Ladybird beetle is presented in the Figure 3. The lady bird beetle was found to occur in the jute field from $5^{\text {th }}$ May to $30^{\text {th }}$ July. The highest number of Ladybird beetle was recorded on $25^{\text {th }}$ June. On the other hand, the lowest number of Ladybird beetle was recorded on $5^{\text {th }}$ May. After reaching to a peak in the last week of June a sharp and then steady decline in the population of the predator was observed.

\subsection{Miridbug, Nesidiocoris Tenuis}

Mirid bug is a widely distributed very important predator of a number of pests. It is a generalist predator that is commonly found on solanaceous plants including tomato. It preys on many small invertebrates, such as whitefly and mites. It also thrives on eggs of lepidoptera. The mirid bug, $N$. tenuis has not been reported as a predator of jute yellow mite earlier in Bangladesh. It was noted that all the stages of $N$. tenuis are good predators.

3.5.1 Systematic Position

Phylum: Arthropoda

Class: Insecta

Order: Hemiptera

Family: Miridae

Genus: Nesidiocoris

Species: Nesidiocoris tenuis

\subsubsection{Predation Rate of Mirid Bug}

The predation rate of the nymphs of the mirid bug was studied in the laboratory. The nymph of the bug was found as voracious predator and consumed as many as $37 \pm 1.17$ yellow mite per hour at the room temperature condition of $26.3 \mathrm{oC}$ and relative humidity of $75.3 \%$. 


\subsubsection{Seasonal Incidence of Mirid Bug}

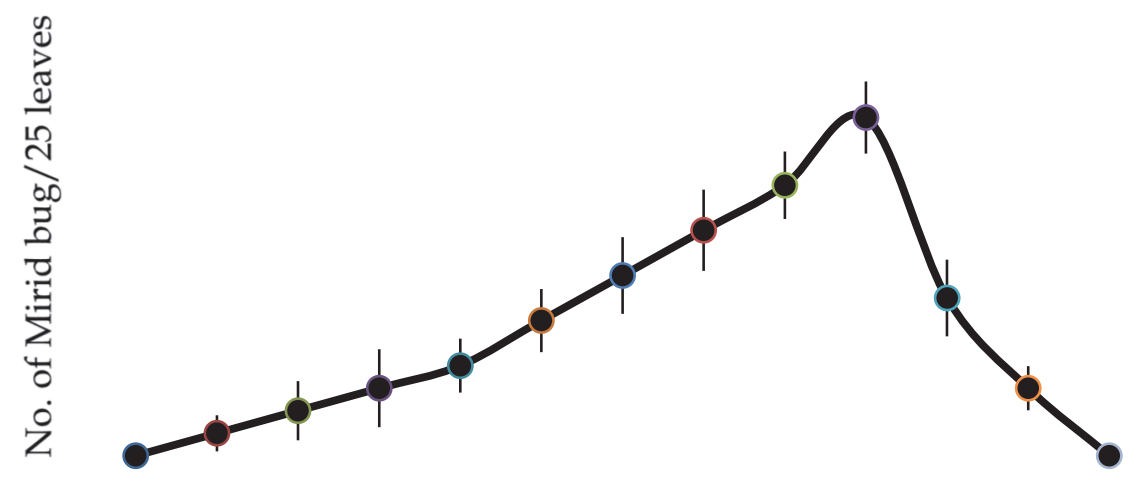

Date of Observation

Figure 5. Seasonal incidence of Mirid bug in experimental field in Central station, BJRI during 2012

The seasonal incidence of Mirid bug is shown in Figure4. The incidence of Mirid bug was observed from mid May to mid July, 2010. The highest of 15 Mirid bugs was recorded at $30^{\text {th }}$ June, 2010. Activity of the mirid bug started in the middle of May aontinued to increase its population to the end of June which then showed a sharp fall during the first half of July.

\subsection{Spider}

\subsubsection{Systematic Position}

Phylum: Arthropoda

Class: Arachnida

\section{Order: Araneae}

\section{Family: Thomisidae}

Spider is a good predator of mites. A species of spider was found to consume yellow mite. This particular species of spider could not be identified up to the species level. It was not also reported previously in Bangladesh as a predator of mite. Preliminary predation performance of the spider on yellow mite of jute has been investigated. It consumed on an average of 18 yellow mites per hour. 


\subsubsection{Seasonal Incidence of the Spider}

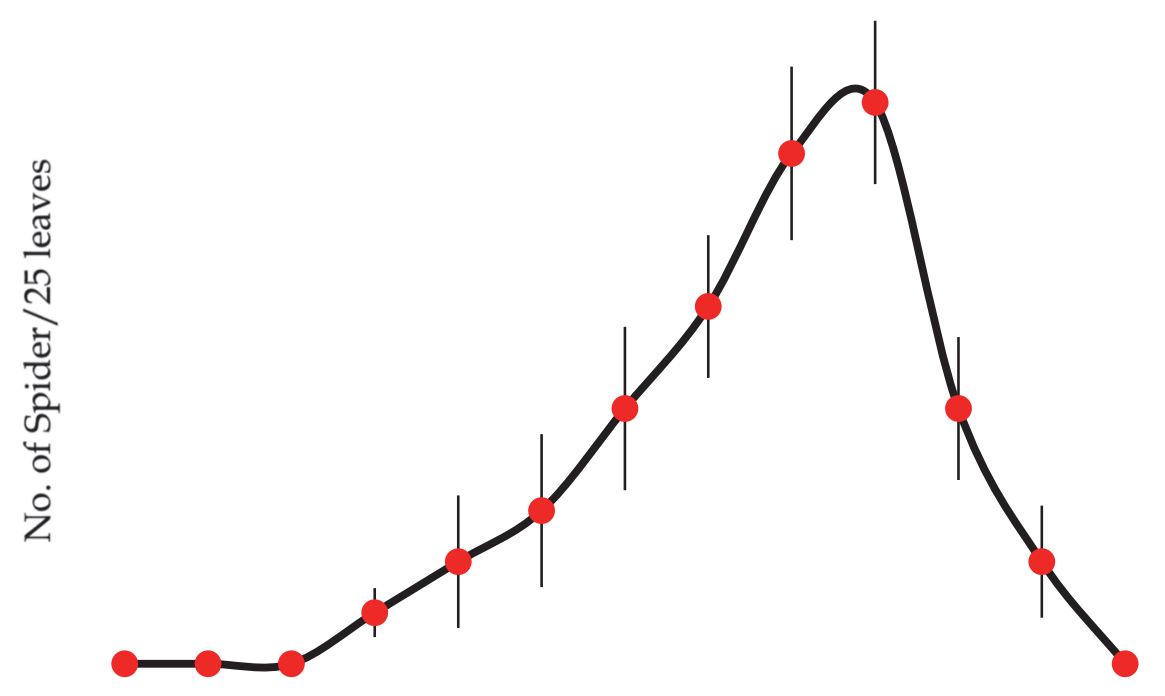

Date of Observation

Figure 6. Seasonal incidence of spider in experimental field in Central station, BJRI during 2012

Incidence of the spider recorded in the central station of BJRI in the year 2010 is presented in the figure 5 . The presence of the spider was first evident by the end of May. Then it increased its number and reached the peak on $30^{\text {th }}$ June. A maximum of 11 spiders were found to occur per 25 leaves of jute plant.

\subsection{Red Bug}

Red bug, a good predator of both the jute yellow mite and red mites is commonly found to predate in its nymphal stage and the predation performance of it indicates that a considerably higher number of yellow mites (22) could be consumed per hour in laboratory condition. Rashed (2006) reported a much higher predation rate of 59 red mite per hour. This might be for the preference of the predator for red mite as prey. Seasonal synchrony between the predator and prey was evident as it occurred during May to August. 


\subsubsection{Seasonal Incidence of Red Bug}

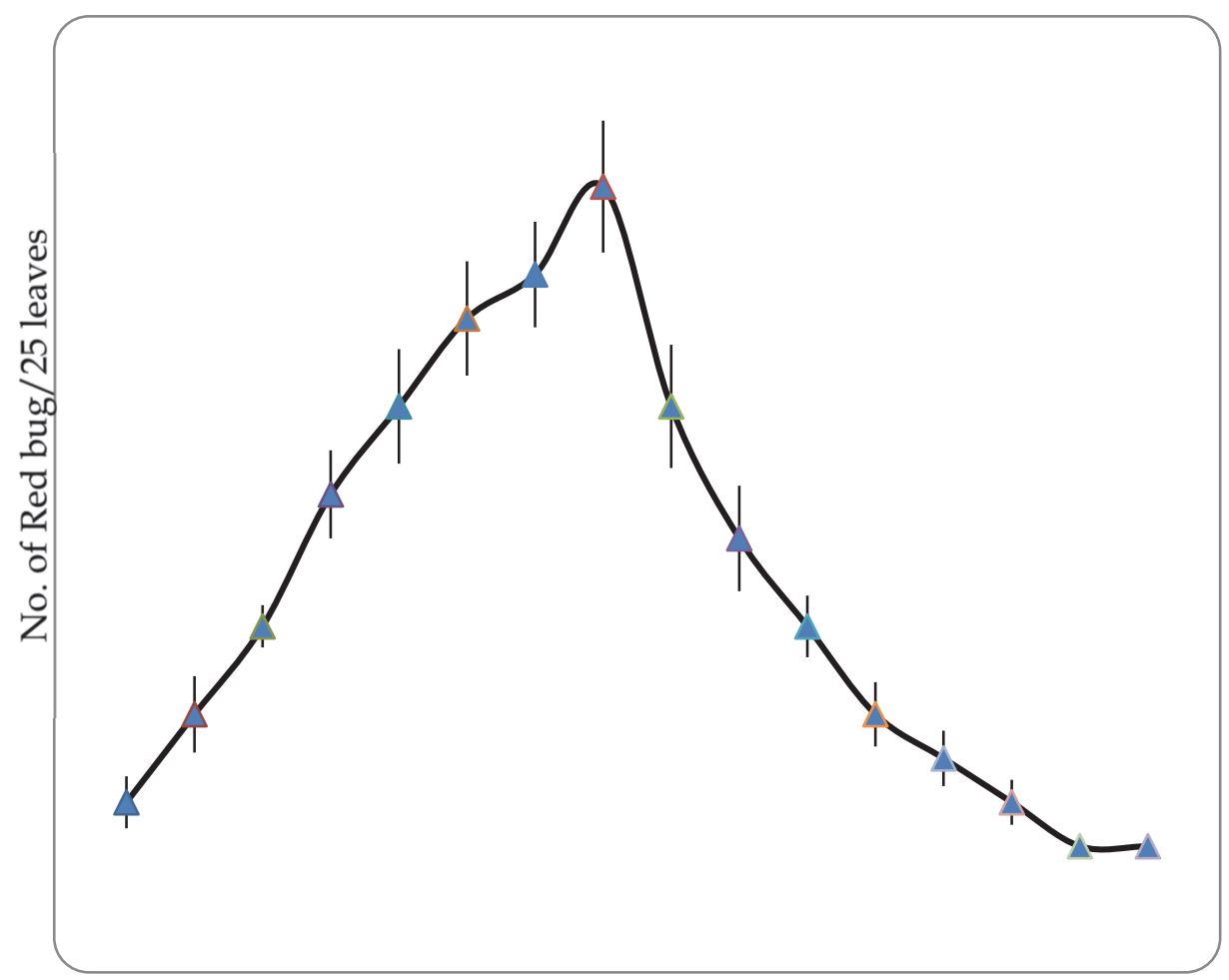

\section{Date of Observation}

Figure 7. Seasonal incidence of Red bug in experimental field in Central station, BJRI during 2012

\subsection{Slender Spring Tails}

Insect of the order Collembola is rarely found. In the jute field of central station of BJRI the slender spring tail , a member of Collembola was found. This particular Collembola could not be identified but found to predate on jute yellow mite. It was not reported in Bangladesh as a predator of mites. This spring tail is also called slender spring bug.

\section{Discussions}

As many as nine predators of jute yellow mite were recorded from CRS, Dhaka during 2011 to 2013. The investigation on the potentiality of the predators against the pest yellow mite indicates their importance to be used in bio-control program.

\subsection{The Predatory Mite}

The predatory mite Amblyseius sp. could be considered very important predator for its presence in the whole jute growing season and predating all the stages of yellow mite. Importance of Amblyseius sp. as predatory mite of jute mites was reported by many other authors (Bonde, 1989; Hunter, 1997;Rashed, 2006). Rashed (2006) observed that the similar consumption rate of predatory mite as has been recorded in the present study. Cross (1984) showed that introductions of predatory mites in March or early April at a rate of one mite per plant were consistently successful.

\subsection{The Thrips}

The thrips (Scolothrips) are are very small, yellow and red in colour but transparent or whitish in colour in immature stage. They have short developmental period and shorter live span. Both the nymph and adult are very active predators showing predation on yellow mite irrespective of egg, nymph or adult. The predation performance of the adult was higher than that of the nymph of the thrips. The nymph and adult of Scolothrips were found to 
consume an average of 15.4 to 20.10 yellow mites per hour. A good synchrony between the yellow mite and the predatory thrips also exist in the field.

\subsection{Minute Pirate Bug}

Minute pirate bug (Orious insidiosus) nymph and adult were observed to predate an average of 24.5 and $21 \pm 1.45$ yellow mites of all stages per hour indicating an efficient predator of the pest although the rate of predation might differ from time to time depending upon the environmental temperature. Both the nymph and adult of Orius sp. predate yellow and red mite of jute but prefer jute yellow mite. Rashed (2006) reported that the predation rate nymph and adult of minute pirate bug ranged from 30 to $32 \mathrm{egg}$, nymph and adult of yellow mite per hour which is higher than the result of the present study. However, the predation performance of both the stages of the minute pirate bug indicates its high potentiality to reduce the population of the yellow mite in jute field. Seasonal abundance of the bug also indicates a good synchrony with its prey.

\subsection{Lady Bird Beetle}

Lady bird beetle was found as most frequent predator of red mites but could predate on yellow mite to a considerable extent. They remain mainly located under surface of leaves where there are mites of different stages. Frequent movement all around from tender leaves to older leaves of the jute plants in search of prey mainly during the morning and evening was noticed. Although both the grubs and adults predate on all the stage of yellow mite but the later was found as voracious feeder showing the predation efficiency of 35 individuals per hours. The lady bird beetle was found to occur in the jute field from $5^{\text {th }}$ May to $30^{\text {th }}$ July showing a good coexistence in the field.

\subsection{Mirid Bug, Nesidiocoris Tenuis}

Mirid bug, a widely distributed generalist predator commonly found on solanaceous plants including tomato was found preying on many small invertebrates, such as whitefly, mites and others. It should be noted here that this particular bug has been documented for the first time in Bangladesh. All the stages of $N$. tenuis are good predators. The nymph of the bug could be considered as voracious predator as it showed a consumption performance of 37 yellow mite individuals in an hour. The seasonal incidence of Mirid bug is showed that it occurs in between May and July.

\subsection{Spider}

A spider species which could not be identified was found to consume yellow mite. This is also a first record as a predator of mite in Bangladesh. Preliminary predation performance of this spider showed that it could consume on an average of 10.56 yellow mites per hour. The presence of the spider was first evident by the end of May and reached its peak on $30^{\text {th }}$ June.

\section{Conclusion}

As many as six predators of jute yellow mite viz, Predatory mite, Thrips, Minute pirate bug, Lady bird beetle, Mirid bug and Spider were identified which will be used as bio-control agent to control jute yellow mite. Chemical pesticide is the main tools for pest management. Every chemical has hazardous effect to environment. Considering green world, this study will help to keep environment free from chemical pollution.

\section{Conflict of Interest}

The authors have no conflict of interest to disclose.

\section{Authors' Contributions}

Md. Nazrul Islam conducted the experiment and analyzed the data. Khandakar Shariful Islam and Mahbuba Jahan provided help for the experimental design and supervised in the whole experiment. Md. Sohanur Rahman contributed in data presentation, analysing data, searching journal for publication and finally manuscript processing \& writing of this article. This article was read and approved by all authors for final Publication.

\section{References}

Anonymous. (1990). Annual report of Bangladesh Jute Research Institute, Manik Miah Avenue, Dhaka-1207. pp. 234.

Anonymous. (2005). Broad mite. Insect and Related pests of Flowers and Foliage Plants. Retrieved September 13, 2005, from http://mrec.ufl.edu/lso/entomol/ncstate/mitel.htm

Banks, N. (1904). Class III, Arachnida, Order 1, Acarina, four new species of injurious mites. J. of New York Entomol. Soc., 12, 53-56.

Bhaduri, M., Gupta, D. P., \& Ram, S. (1989). Effect of vegetable oils on the ovipositional behaviour of 
Callosobruchus maculatus Fab., 81-84. In. Proc. $2^{\text {nd }}$ Int. Symp. On Bruchids and Legumes (ISBL-2), Okayama (Japan), September, 1989. https://doi.org/10.1007/978-94-009-2005-7_8

Bonde, J. (1989). Biological studies including population growth parameters of the predatory mite Amblyseius barkeri (Acarina: Phytoseiidae) at $25{ }^{\circ} \mathrm{C}$ in the laboratory. Entomophaga, 34, 275-287. https://doi.org/10.1007/BF02372676

Cross, J. V. (1984). Biological control of two-spotted spider mite (Tetranychus urticae) by Phytoseiulus persimilis on strawberries grown in "walk-in" plastic tunnels, and a simplified method of spider mite population assessment. Plant Pathology, 33, 417-423. https://doi.org/10.1111/j.1365-3059.1984.tb01337.x

Denmark, H. A. (1980). Broad mite, Polyphagotarsonemus latus (Banks). FDACS-DPI Bureau of Entomol. Circular No. 213. pp. 2.

Fishwick, R. B. (1988). Pesticide residues in grain arising from post harvest treatments. Aspects Appl. Biol., 17(2), 37-46.

Fukuda, H. (1966). Rice insect control by granular insecticide. JARQ, 1(1), 17-21.

Georghiou, G. P., \& Taylor, C. E. (1977). Pesticide resistance as an evolutionary phenomenon. Proc. XV. Int. Congr. Ent. pp.759.

Goodland, R., Watson, C., \& Ledac, G. (1985). Biocides bring poisoning and pollution to third world. The Bangladesh Observer. $16^{\text {th }}$ and $17^{\text {th }}$ January, 1985.

Hagen, K. S., \& Franz, J. M. (1973). A history of biological control. Annual Rev. Inc. Palocetto, California.pp. 872.

Hunter, C. D. (1997). Suppliers of Beneficial Organisms in North America (PM 97-01). California Environmental Protection Agency, Department of Pesticide Regulation Enviornomental Monitoring and Pest Management. Sacramento, CA. USA. pp.32.

Iacob, N. (1978). New Mite Pests on Greenhouse Crops and on Grapevine (abstract only). Rev. Appl. Entomol. Ser. A., 67(12), 595-596.

Kabir, A. K. M. F. (1979). Bioecology and behavior of yellow jute mite. In:J.G.Rodriguez(Editor),Recent Advances in Acarology, Vol.1. Academic press, New York. Pp. 519-523. https://doi.org/10.1016/B978-0-12592201-2.50073-7

Kabir, A. K. M. F. (1975). White mite, Hemitarsonemus latus (Banks) Ewing. In jute pests of Bangladesh. Bangladesh Jute Research Institute. Dhaka, Bangladesh. Pp. 28-33.

Karuppuchamy, P., \& Mohanasundaram, M. (1987). Bioecology and control of chilli muranai mite. P. latus (Banks). Int. J. Plant Prot., 15, 1-4.

Kavadia, V. S., Pareek, B. L., \& Sharma, K. P. (1986). Residues of malathion and carbonyl in stored sorghum. Bull. Grain Tech., 22(3), 247-250.

Moutia, L. A. (1958). Contribution of the study of some phytophagous Acarina and their predators in Mauritius. Bull. Entomol. Res., 49, 59-75. https://doi.org/10.1017/S0007485300053438

Munakata, K. (1977). Insect feeding deterrents in plants. In Shorey, H. H., \& J. J. Mckelvey Jr. (Eds.), Chemical control of insect behavior (pp. 93-102). John Wiley and Sons. New york.

Nemesthoty, K., Volcsansky, E., Simon, N. (1982). Influence of damage of the mites Tarsonmus pallidus and Polyphagotarsonemus latus Banks (Acari:tarsonemidae) on the morphological properties of fashedera and hedera leaves. Novenyvedelem, 10, 437-442.

Pimentel, D. (1981). An overview of integrated pest management (Mimeograph). Dept. of Entomol, Section of Ecology and Systematic, Cornel Universit, Ithaca, New York. pp. 52.

Pimentel, D. (1977). Ecological basis of insect pest, pathogen and weed problems: In origin of pests, parasites, disease and weed problems. Oxford Blackwell's Scientific Publications. pp. 3-13.

Rashed. (2006). investigation on the natural enemies of jute white mite Polyphagotarsonemus latus (Banks) \& Jute red mite. Tetranychus bioculatus(Wood-Mason). pp.65.

Schmutterer, H., Saxena, R. C., \& Heyde, V. (1983). Morphogenetic effects of some partially purified fractions and methanolic extracts of neem seeds on Mythimna separate Walker and Cnaphalocrosis medinalis. G. Z. Angew. Ent. 95, 230-237. https://doi.org/10.1111/j.1439-0418.1983.tb02637.x 
Siddique, M. A. B., \& Kabir, A. K. M. F. (1978). Mating behaviour, infestation and alternate hosts of jute mite. Bangladesh J. Agric., 4, 121-126.

Waiss, A. C. J. R., \& Chen, B. C. (1981). Insect growth inhibitor in crop plants. ESA Bulletin, 27(3), 217-221. https://doi.org/10.1093/besa/27.3.217

\section{Copyrights}

Copyright for this article is retained by the author(s), with first publication rights granted to the journal.

This is an open-access article distributed under the terms and conditions of the Creative Commons Attribution license (http://creativecommons.org/licenses/by/4.0/). 